\title{
O PROCESSO DE COMPOSIÇÃO DO TRIBUNAL ARBITRAL INTERNACIONAL E O SEU FUNCIONAMENTO
}

\author{
Luiz Fernando Vescovi ${ }^{1}$
}

\section{RESUMO}

O presente trabalho vem a delinear, sob forma objetiva, o efetivo escopo de um Tribunal Arbitral, ponderando as suas características e o comprometimento com as partes que a elegem. Apresenta o procedimento e 0 processo de como se constitui um tribunal dessa espécie, assim como as vantagens existentes quando da sua utilização. Enfatiza, de plano, a escolha dos apreciadores do juízo arbitral, assim como a análise circunstancial sobre a incidência da Lei de Arbitragem brasileira à luz do Direito supranacional. Enaltece a viabilidade jurídica (segurança e validade) que o instituto arbitral expressa, concernente às disposições principiológicas que dele decorrem. Ainda, descreve, de maneira esmiuçada, a forma de como o Tribunal Arbitral se compõe, sua competência, prerrogativas e finalidades, bem como do funcionamento efetivo, no plano do Direito Internacional Privado.

\section{ABSTRACT}

This work intends to, in an intuitive way, draw the guidelines of an Arbitration Court, by analysing its characteristics and the compromise existent between it and the parties who elect it. It seeks to present the procedures and the process by which means such a Court is constituted, as well as the advantadges coming from the use of this kind of Court. It emphasizes the choice of those who will appreciate the arbitrational judgement, as well as the circumstantial analysis of the brazilian Arbitration Law's effect under the light of the supra-national Law. It exposes the juridic viability (secureness and validity) which is expressed by the arbitrational institution, concerning the principle-

\footnotetext{
${ }^{1}$ Bacharel em Direito pelo UnicenP - Centro Universitário Positivo, pesquisador do NDI/UFPR - Núcleo de Estudos em Direito Internacional da Universidade Federal do Paraná e da ABDConst - Academia Brasileira de Direito Constitucional.
}

Revista Brasileira de Direito Internacional, Curitiba, v.2, n.2, jul./dez.2005 
based dispositions which arise from said institution. Finally, it describes, in a detail-rich manner, the way an Arbitration Court is composed, its competences, prerogatives, and purposes, and how it effectively works, within the premise of the Private International Law.

Palavras-chave: Tribunal arbitral - composição - Direito internacional privado.

Keywords: Arbitration Court - creation - Private International Law.

\section{NOTAS INTRODUTÓRIAS}

O Estado, como poder único, (soberano e absolutista) de determinada coletividade acabou, há tempos, limitando (com certo rigor) a autocomposição como maneira de solucionar pendências de ordem litigiosa, das partes pelas próprias partes. O modo existente de análise de lides, atualmente, é tãosomente pela via judicial, sem com que outra forma, portanto, seja possível.

Ao que se entende, hoje em dia, da prestação jurisdicional ordinária (ou seja, aquela oriunda do Poder Judiciário de determinado país), não há divergência sobre a validade e eficácia de seu escopo primordial: o serviço apreciativo de processos contenciosos. Assim se afirma pelo fato de que, em tal órgão, a análise (processamento e julgamento) das lides que se prestam acerca da intervenção estatal, é o seu desempenho laboral efetivo.

A arbitragem, regulamentada pela Lei № 9.307, datada do ano de 1996, é um instituto que ainda se manifesta novo no plano das formas existentes de solução de controvérsias. Sua aplicação ainda é tímida na esfera do Direito Internacional Privado, tendo em vista que a possibilidade de a ela se alcançar apresenta-se limitativa, quando comparado às maneiras clássicas de apreciação de litígios dessa natureza.

A intervenção dos Tribunais Arbitrais, porém, como forma caracterizadora de solução de conflitos em âmbito internacional, ainda encontra-se em fase de expansão, bem como de "confiança" àqueles que dela se socorrem, por serem regidas, em grande parte (e este é o objeto do presente estudo), pela iniciativa privada. Sua composição se dá, na maioria das 
vezes, por meio de acordo prévio entre os litigantes sobre a escolha do(s) árbitro(s), foro, legislação e até o procedimento a ser adotado, dependendo de cada caso in concretu.

De toda sorte, tem-se o instituto arbitral internacional como espécie de resguardo de direitos privados, estes, de sujeitos referentes a países diversos, com o fim igualitário, que é a sentença arbitral resultante do deslinde por eles proposto. Essa espécie inovadora de "prestação jurisdicional" acaba por dar ensejo à voluntas pars, remetendo ao modo apreciativo de lides privadas, pela força que tal vontade apresenta, solidificando, em termos, o meio "autocompositivo" que foi limitado, historicamente arrazoado, pelo poder estatal.

A flexibilidade originária de um tribunal dessa espécie de apreciação litigiosa, fundada na possibilidade de as partes acordarem certas prerrogativas, faz com que seu funcionamento (procedimental) torne-se menos formalista, mas não menos efetivo e/ou desprovido de respeito e credibilidade sobre as sentenças que venham a proferir, quando provocado para tanto.

A maneira, então, de como se forma um juízo arbitral, no plano internacional, visando a tutela e pronunciamento de ordens jurídicas (por meio das sentenças ou laudos arbitrais pronunciados), tal como as prerrogativas que Ihe anseiam, fazem-se dignas de entendimento meticuloso, para que seu objetivo seja tanto abalizado quanto alcançado, em nível de maior esmero possível.

Nesse sentido, ao juízo arbitral se insere acertado grau de importância, e daí o motivo da compreensão, sob a sua estrutura basilar e funcional, no que se refere aos litígios de ordem supranacional, bem como das soluções delas advindas, por meio das sentenças dos Tribunais Arbitrais. A estrutura a qual se alude diz respeito à escolha dos árbitros, ao procedimento a ser adotado, aos laudos proferidos, dentre outros.

Destarte, o surgimento da arbitragem, tanto no plano interno quanto no internacional, trouxe diversidade ponderável acerca da forma jurisdicional preexistente, o que representa, sistematicamente, progresso no que diz respeito aos modos evidentes (e viventes) de prestamento jurisdicional. Por 
tudo isso, se tem por primordial a análise do instituto da arbitragem, na órbita internacional, como modelo resolutivo de conflitos interestatais, assim como dos desdobramentos que dela decorrem e, em principal, o momento assertivo da formação do tribunal atinente à sua atividade de alçada laboral.

\section{DISTINÇÃO ENTRE O ACESSO À ESFERA JURISDICIONAL E À JURISDIÇÃO POR VIA ARBITRAL}

Basicamente, a jurisdição existe como sendo algo único, ou seja, o próprio jus dicere, ou o "dizer o direito". Esta acepção clássica conota, principalmente, quando se refere à forma de efetivar a prestação jurisdicional como meio possível e viável de alcançar a solução de controvérsias, no plano jurídico.

Cabe, no presente momento, fazer a distinção entre a jurisdição civil tradicional e a forma inovadora atinente à alçada arbitral internacional, seus desdobramentos e pressupostos, assim como cada qual se porta e as finalidades processuais que apresentam.

Acerca do primeiro modo jurisdicional em questão, MARQUES apresenta, sob linhas precisas, qual é o seu escopo primordial e absoluto, numa visão conservadora, porém não menos verdadeira:

\footnotetext{
"Pressuposto, ainda, da jurisdição, é a propositura de ação: nulla iurisdictio sine actione. E, igualmente, o devido processo legal, com o contraditório entre as partes, para que se estruture, adequadamente, o actum trium personarum eu que consiste o processo. Donde poder definir-se a jurisdição civil nos termos seguintes: é a função estatal, exercida no processo, por órgão da justiça ordinária, mediante propositura de ação, a fim de compor um litígio não-penal". 2
}

Sendo conciso em suas palavras, o jurista acima explanado bem descreve o que se tem por jurisdição (civil) na órbita do Direito Processual Civil. O alcance concernente a essa jurisdição, ressalte-se, é tão-somente estatal, não podendo ser extrapolado deste.

\footnotetext{
${ }^{2}$ MARQUES, José Frederico. Manual de direito processual civil. v. 1. São Paulo: Saraiva, 1978. p. 63.
}

Revista Brasileira de Direito Internacional, Curitiba, v.2, n.2, jul./dez.2005 
As ações ordinárias, dignas de competência apreciativa de plano interno são as que compõem a instauração, obviamente, da relação processual interna e, conseqüentemente, o "dizer o direito" nesse sentido.

Para tanto, no que dispõe sobre a competência do exame, processamento e julgamento de lides em Tribunal Arbitral Internacional, a concepção de "jurisdição" difere substancialmente daquela civil, o que reforça a necessidade de distinguirmos, paulatinamente, cada uma.

Havendo, portanto, em mente, que a diferenciação conceitual existe entre os planos civil interno e internacional (na arbitragem) sobre a jurisdição, fica a encargo dos jurisconsultos internacionalistas demonstrarem o que se entende por "jurisdição internacional".

De grande valia é a passagem sobre esse "momento" em estudo de ARAUJO, donde surge a caracterização de como o juízo arbitral internacional se delimita, na sua esfera de competência. In verbis:

\footnotetext{
“A LA não prevê um regime jurídico distinto para as arbitragens internacionais realizadas no Brasil e não define os contornos da arbitragem internacional. Os precedentes doutrinários e jurisprudenciais distinguem-na da arbitragem interna. A arbitragem deve envolver relação jurídica subjetivamente internacional - ou seja, ter partes domiciliadas em paises diversos -, ou conter algum elemento objetivo de estraneidade, isto é, o local de sua constituição, do cumprimento da prestação, etc". 3
}

Confrontando os ensinamentos dos dois juristas supracitados, cada um em sua esfera de estudo, é possível perceber a distinção que se afirma existir. Enquanto que a jurisdição civil interna se atém à apreciação de controvérsias oriundas de partes domiciliadas no seu território de jurisdição, tal como os elementos limitativos que a este consistem, na alçada internacional sua prestação se tem mais abrangente, ou seja, os pólos da relação em contenda devem estar em congruência com um ou mais elementos de estraneidade, ou então em países diversos, dentre outros.

Vale dizer que a formação dos "tipos" de jurisdição, nestes âmagos, são diferenciados pela função que cada um desempenha. Por isso mesmo, não se tem por pretensão a explanação de que um é superior, no sentido de

\footnotetext{
${ }^{3}$ ARAUJO, Nadia de. Direito internacional privado: teoria e prática brasileira. 2.ed. Rio de Janeiro: Renovar, 2004. p. 427.
}

Revista Brasileira de Direito Internacional, Curitiba, v.2, n.2, jul./dez.2005 
relevância, em relação ao outro, precisamente por compreendermos que isso não se assinala verdadeiro.

A prestação jurisdicional que nos interessa na presente análise diz respeito à última que foi explanada, qual seja: a jurisdição no momento internacional e em especial nos tribunais arbitrais com competência internacional. Por isso, entendemos ser, ambas as formas jurisdicionais, preponderantes, mas aquela que se refere ao tribunal arbitral se mostra mais abarcado, por haver a possibilidade de aplicação efetiva do "princípio da autonomia das partes", que será averiguado em momento oportuno.

A formação da jurisdição, sob a ótica internacional, então, compreende norteamentos que devem ser seguidos, com o intuito de que o instituto arbitral seja utilizado para fins de soluções litigiosas específicas. É nesse plano que MELLO, mais tendencioso ao Direito Internacional Público do que realmente ao Privado, apresenta os três caminhos a serem obedecidos atualmente, pelo juízo arbitral:

\footnotetext{
"Três direções podem ser apontadas como sendo as tendências da arbitragem nos dias de hoje: a) a arbitragem é obrigatória para certos litígios; b) submissão à arbitragem dos litígios políticos; c) a reserva estabelecendo que as questões relativas à honra e à soberania do Estado não são submetidas à arbitragem está desaparecendo gradativamente (Rousseau)". 4
}

Parece-nos, por arremate, que a análise da conceituação e distinção existentes entre as formas jurisdicionais de um ordenamento jurídico interno e um internacional, principalmente na diferenciação daquele como "civil" e deste como "oriundo da arbitragem", torna-se complicada, porém necessária para que o entendimento acerca dos pressupostos e desdobramentos peculiares do Tribunal Arbitral seja viável. Não obstante, trazendo à baila tais explanações, fica contornável que essa dicotomia existe e precisa, como iniciação ao exame da formação do Tribunal Arbitral, ser perpetrado, conforme discorrido até o presente.

\footnotetext{
${ }^{4}$ MELLO, Celso D. de Albuquerque. Curso de direito internacional público, v.2. 13.ed. Rio de Janeiro: Renovar, 2001. p. 1386.
}

Revista Brasileira de Direito Internacional, Curitiba, v.2, n.2, jul./dez.2005 
3 ÁRBITROS PASSÍvEIS DE ESCOLHA E SUAS ATRIBUIÇÕES AO TRIBUNAL

Antes mesmo de se adentrar na questão atinente daqueles que podem figurar no árduo cargo de árbitro ou mesmo de poder resolver certa controvérsia, no plano internacional, é preciso que se conceitue "árbitro" propriamente dito, bem como suas investiduras.

Neste ponto, LEE é quem melhor o caracteriza, de maneira bastante precisa e criteriosa, apresentando a função maior de um árbitro num tribunal arbitral. A ressalva que se faz é de que sua análise é no plano do Mercosul, porém, dá grande base para compreender a função à ele relativo. In verbis:

\footnotetext{
"O árbitro é investido de um poder jurisdicional pelas partes. Esta investidura privada de uma função jurisdicional caracteriza o estatuto do árbitro. Desta forma, o direito paraguaio confere ao árbitro um estatuto idêntico ao do juiz. O árbitro, aliás, apresenta uma dupla face: ele é ao mesmo tempo juiz e prestador de serviços. Como os países do Mercosul não trazem nenhuma precisão sobre o outro componente de seu estatuto, somente a função jurisdicional do árbitro será analisada neste estudo".
}

Ao que concerne, portanto, sobre a escolha dos árbitros que irão constituir determinado tribunal arbitral, tal ponto se apresenta de grande relevância, tendo em conta que a esses será conferida a prerrogativa de se portar como os juízes efetivos, que irão processar e julgar os casos concernentes ao órgão arbitral.

Essa dificuldade de se nomear árbitros capacitados para 0 processamento da causa está principalmente no fato de que as partes se valem da possibilidade, assim como no plano jurisdicional ordinário interno, de prever impedimentos dos mesmos, por várias naturezas. Dessa forma, não se tem por controvertido que a apreciação do caso pelos árbitros deve ser feita com total imparcialidade (que, por sua vez, é condição sine qua non de validade e eficácia do tribunal arbitral).

Os impedimentos decorrentes da legislação vigente para obstaculizar a atuação de um árbitro, em sua esfera de labor, estão descritos tanto na lei

\footnotetext{
${ }^{5}$ LEE, João Bosco. Arbitragem comercial internacional nos países do Mercosul. Curitiba: Juruá, 2002. p. 123.
}

Revista Brasileira de Direito Internacional, Curitiba, v.2, n.2, jul./dez.2005 
processual civil quanto na própria Lei de Arbitragem, em seus arts. 134 e 135; e 14, respectivamente. Esta última (lei especial) assim dispõe:

\begin{abstract}
“Art. 14. Estão impedidos de funcionar como árbitros as pessoas que tenham, com as partes ou com o litígio que lhes for submetido, algumas das relações que caracterizam os casos de impedimento ou suspeição de juízes, aplicandose-lhes, no que couber, os mesmos deveres e responsabilidades, conforme previsto no Código de Processo Civil".
\end{abstract}

É por tal razão que a escolha condizente daqueles que integram um tribunal arbitral internacional não se faz simples, envolvendo, ainda, fatores que convalidam com a suspeição ou impedimento dos mesmos, quais sejam: nacionalidade, profissão exercida, amizade para com uma das partes e demais.

De toda sorte, mesmo havendo grande gama de possibilidades para que um árbitro seja afastado de determinado caso em análise pelo juízo arbitral, é necessário que as vagas, obviamente, sejam lotadas por estudiosos de conhecimento técnico notório e índole incontestável para que o órgão seja concretamente institucionalizado.

Neste viés, FIGUEIRA JÚNIOR explicita o requisito primordial para que o árbitro, quando contemplado de suas funções e prerrogativas, efetue seu trabalho com grande valia:

\footnotetext{
“O principal requisito para o bom desempenho da função arbitral está intimamente ligado com a escolha adequada do julgador ou julgadores pelos litigantes, que deve atentar não só aos requisitos genéricos e subjetivos do art. 13, caput, mas também para a formação técnica ou científica dos árbitros e as suas respectivas afinidades com a matéria objeto da controvérsia". ${ }^{6}$
}

Havendo sido preenchido, assim, tal pressuposto delineado, o desenvolvimento, de maneira concisa do árbitro, de suas funções, facilmente se dará. Ainda, ressalte-se que seu conhecimento técnico e sua vivência prática ao longo dos anos, acrescido de profissionais capacitados para dar assistência ao seu labor (como é o caso dos assessores, dentre outros), ensejam maior segurança jurídica e competência daqueles que prolatam os laudos, caracterizando a seriedade do órgão ao qual faz parte.

\footnotetext{
${ }^{6}$ FIGUEIRA JÚNIOR, Joel Dias. Arbitragem, jurisdição e execução: análise crítica da Lei 9.307, de 23.9.1996. São Paulo: Editora Revista dos Tribunais, 1999. p. 200.
} 
Por essa linha, ficam habilitados a se constituírem como árbitros num tribunal dessa espécie aqueles que, em conformidade com a disposição legal, estejam em gozo pleno da capacidade civil que lhes integra. A questão secundária, que não menos confere importância e encontra-se disciplinada no art. 13 da Lei ํㅜ 9.307/96, é de que o árbitro eleito deva aspirar confiança das partes do caso em apreço.

Estando, portanto, tais requisitos preenchidos (não sendo imperativo o bacharelado em Direito como condição para tal), não há outro obstáculo para que alguém denote competência para a nomeação.

Compreendida, nesta etapa, a conceituação de "árbitro" e as funções que lhe apetecem, tem-se o emblemático problema a ser resolvido quanto à escolha dos mesmos; o número de árbitros componentes do tribunal arbitral e a finalidade maior da constituição de determinado tribunal, por determinados juízes arbitrais, que serão, em momento oportuno, estudados ad cautelam.

Prevalece entendimento (e assim ocorre em grande parte dos juízos arbitrais), de que a escolha dos apreciadores é instituída pelos próprios litigantes de caso in concretu e que àquele órgão apreciativo se submetem.

A faculdade concedida às partes para a escolha de seus árbitros prega embasamento de que, estando ambas as partes em comum acordo e conscientes de seus julgadores, tal qual da origem e graduação técnica que trazem consigo, os árbitros eleitos ficam mais "seguros" de sua autoridade e apreciação e os litigantes também mais "seguros" da seriedade, respeito e imparcialidade do laudo proferido. A forma de escolha destes também poderá ser regrada pela vontade dos litigantes.

No sentido de escolha arbitral, MAGALHÃES apresenta, em interessante estudo, sua forma de compreender esta indicação. Nestes termos, pela importância que tal passagem expõe, se faz, a seguir, a transcrição:

\footnotetext{
"Há que se considerar, ainda, que a parte, ao indicar o árbitro, não designa pessoa que vai esposar seu ponto de vista, necessariamente. A nomeação leva em consideração as qualidades pessoais e profissionais, a reputação e, principalmente, os conhecimentos específicos da pessoa indicada, sobre o assunto levado à arbitragem. Tratando-se de controvérsia de caráter internacional, é natural que as partes indiquem, como árbitros, não lho
} 
vedando a convenção arbitral, nacionais do país em que se desenvolve a arbitragem, ou cuja lei aplicável à relação jurídica controvertida". ${ }^{7}$

A colocação primordial desse ponto, então, atém-se na salvaguarda de um dos princípios de maior preponderância na órbita do Direito Internacional Privado, qual seja: o princípio da autonomia da vontade.

Fator outro anteriormente citado é quanto ao número de árbitros componentes do tribunal. Neste cerne, o número sempre será ímpar, para que, nos votos dos mesmos, não assinale o empate, pelo colégio arbitral.

A quantidade de árbitros também respeitará a autonomia das partes, podendo ser de tão-somente um, ou então de três, cinco, etc. e também, caso haja disposição neste sentido, o estatuto arbitral. Assim, constituído o colégio, será designado o presidente do mesmo por voto simples dos participantes e, caso não seja acatada a escolha, a Lei de Arbitragem, em seu art. 13, § 4ํㅡㄴ, prevê a presidência àquele mais ancestral participante do colégio.

No que concerne à esfera do Mercosul, porém, existe restrição, segundo LEE, variando para cada Estado-membro militante, e suas respectivas legislações. ${ }^{8}$

Em estima ao que se tem explanado, a escolha dos árbitros não é tarefa fácil, visto que o preenchimento de requisitos essenciais deve ser atendido e, após a opção feita, haver mútuo respeito, tanto no plano horizontal (das partes em relação a elas mesmas, acerca da escolha) quanto no plano vertical (do árbitro para com as partes e vice-versa). Sendo assim, a cautela deve sempre imperar quando da preferência do(s) julgador(es), visando que a este esteja investido de justiça para o desenvolvimento ideal de seu labor.

\section{PROCEDIMENTO ARBITRAL}

Primeiramente, para que se possa averiguar no que consiste 0 procedimento em instância arbitral, é preciso tomar em conta o que se tem por

\footnotetext{
${ }^{7}$ MAGALHÃES, José Carlos de. Do procedimento arbitral, p. 155-169. In: PUCCI, Adriana Noemi (coord.). Aspectos atuais da arbitragem: coletânea de artigos sobre arbitragem. Rio de Janeiro: Forense, 2001. p. 164.

${ }^{8}$ LEE, João Bosco. Arbitragem comercial internacional nos países do Mercosul. Curitiba: Juruá, 2002. p. 136.
}

Revista Brasileira de Direito Internacional, Curitiba, v.2, n.2, jul./dez.2005 
procedimento propriamente dito. Acerca da conceituação de procedimento, então, pode-se afirmar como sendo um conjunto de regramentos, sistematicamente elencados, visando a predeterminação de atos a serem praticados dentro de determinado processo.

Nesse sentido, imaginando o procedimento judicial e $\mathrm{o}$ arbitral, em primeiro momento, nos parecem equivalentes, porém, alguns atos se fazem privativos da via judicial enquanto que outros se mostram somente inerentes à esfera arbitral. Limitamo-nos, aqui, à averiguação do procedimento arbitral (seu processo e jurisdição).

O momento arbitral se apresenta iniciado quando se tem por escolhido, pelas partes litigantes, o(s) árbitro(s) que irão analisar o caso in concretu. Havendo, então, a instauração, compete ao juízo arbitral o pronunciamento sobre o acordo arbitral para depois dar início aos trabalhos de "litigância" (exame de documentos, dentre outros), com o fim de não dar oportunidade, via de regra e quando possível, a contestação do laudo arbitral proferido posteriormente. ${ }^{9}$

O compromisso arbitral, firmado pelas partes com a finalidade de dirimir litígios decorrentes de obrigação não prevista contratualmente, havendo, assim, a nomeação dos árbitros anteriormente consultados, conforme disciplina MAGALHÃES, acaba por subscrever o instituto, coincidindo a abertura do processo de arbitragem com a sua própria composição. ${ }^{10}$

Assim, basicamente, se dá o procedimento arbitral nos planos do Direito Internacional e Interno, apenas possuindo a necessidade de chamar a atenção aos sujeitos de direitos internacionais daqueles ao enfoque maior do presente estudo: o Direito Internacional.

Ao tribunal arbitral, então, justificado pela autonomia das partes intrínseca em seu bojo, tem-se menor formalismo no que tange ao procedimento, pelo instituto, adotado em relação àquele judicial comum. Assim, estando desprovido de tal "rigidez" processual, aos litigantes se tem maior

\footnotetext{
${ }^{9}$ ROQUE, Sebastião José. Arbitragem: a solução viável. São Paulo: Ícone, 1997. p. 69.

${ }^{10}$ MAGALHÃES, José Carlos de. Do procedimento arbitral, p. 155-169. In: PUCCI, Adriana Noemi (coord.). Aspectos atuais da arbitragem: coletânea de artigos sobre arbitragem. Rio de Janeiro: Forense, 2001. p. 156.
}

Revista Brasileira de Direito Internacional, Curitiba, v.2, n.2, jul./dez.2005 
possibilidade de opinar, nos limites que o instituto arbitral escolhido estipula, junto ao órgão julgador. Em relação a isso, tal como do procedimento propriamente dito, descreve ROQUE:

"O juízo ad hoc é exercido por um tribunal estabelecido pela convenção
arbitral para examinar aquela questão. As partes dizem se funcionará apenas
um árbitro ou um colegiado e quem serão os árbitros, onde e quando será o
julgamento e o direito aplicável e os passos processuais adotados. Cabe a
elas, ainda, adotar outras medidas. A arbitragem dar-se-á nas bases por elas
estabelecidas, de forma livre. Com o julgamento, a arbitragem estará extinta.
Se as mesmas partes tiverem outra divergência, poderão instituir outra
arbitragem, como outro procedimento". ${ }^{11}$

Caracteriza-se o procedimento arbitral a partir das disposições do art. 19 da Lei de Arbitragem, contudo, sua formação se faz consistente desde o acordo e/ou compromisso efetuado pelos litigantes, passando pela nomeação dos árbitros competentes (sua aceitação), dentre outros momentos procedimentais, conforme descreve o parágrafo único do referido artigo: "Parágrafo único. Instituída a arbitragem e entendendo o árbitro ou o tribunal arbitral que há necessidade de explicitar alguma questão disposta na convenção de arbitragem será elaborado, juntamente com as partes, um adendo, firmado por todos, que passará a fazer parte integrante da convenção de arbitragem".

Não se pode deixar de destacar, apenas em sentido de apresentação, fundado na importância que exprimem ao instituto da arbitragem internacional, os princípios nele incidentes. São eles: a) Princípio do contraditório; b) Princípio da igualdade das partes; c) Princípio da imparcialidade; d) Princípio do livre convencimento. Dessa forma, para que o procedimento arbitral seja efetivamente constituído, devem tais princípios, ser seguidos à risca.

Além destes, três são as circunstâncias que se aplicam ao procedimento de natureza arbitral, nos dizeres de FIGUEIRA JÚNIOR, são eles: a) as partes definem o rito procedimental na convenção de arbitragem; b) o procedimento será definido pelo órgão arbitral institucional ou entidade especializada ou pelo árbitro ou tribunal, conforme indicação das partes na

${ }^{11}$ ROQUE, Sebastião José. Arbitragem: a solução viável. São Paulo: Ícone, 1997. p. 72.

Revista Brasileira de Direito Internacional, Curitiba, v.2, n.2, jul./dez.2005 
convenção arbitral; c) não havendo estipulação acerca do procedimento, caberá ao árbitro ou colégio arbitral discipliná-lo. ${ }^{12}$

Não se pode deixar passar in albis o fato de que a Lei de Arbitragem, ora analisada, convalida-se em duas convenções bastante relevantes para tal análise, quais sejam: a Convenção de Nova lorque e a Convenção do Panamá, que ensejam, por sua vez, em nossa lei, todo o procedimento arbitral em estudo.

Advirta-se que a despeito das convenções internacionais, COELHO explicita a situação do Brasil frente à Convenção do Panamá (1975):

\footnotetext{
"No plano do direito internacional, o Brasil ratificou a Convenção Interamericana sobre Arbitragem Comercial Internacional, assinada no Panamá em 30 de Janeiro de 1975 (aprovada pelo Congresso Nacional, nos termos do Decreto Legislativo $n^{\circ}$ 90, de 6 de Junho de 1995, e promulgada pelo Presidente da República, nos termos do Decreto ${ }^{\circ}{ }^{1.902, \text { de }} 9$ de Maio de 1996)". ${ }^{13}$
}

Em apreço à Convenção de Nova lorque (1958), porém, esclarecem PITOMBO e STENER a sua ratificação, por parte do Brasil, como sendo a última da América do Sul, apenas efetuada em ano de 2002. In verbis: "Em 23.07.2002, por meio do Decreto 4.311 foi, finalmente, ratificada pelo Brasil e incorporada ao seu ordenamento jurídico interno a Convenção sobre o Reconhecimento e Execução de Sentenças Arbitrais Estrangeiras, celebrada em 1958 em Nova lorque, mais conhecida como Convenção de Nova lorque". ${ }^{14}$

Fica concluído que aos tribunais arbitrais de jurisdição internacional conferem responsabilidades que Ihes são privativas, tanto no que diz respeito aos requisitos peculiares; aos sujeitos possíveis de litigar nesse plano (que necessariamente devem ser de países distintos), quanto acerca do processamento e julgamento que dela deriva, por estarem presentes a voluntas

\footnotetext{
12 FIGUEIRA JÚNIOR, Joel Dias. Arbitragem, jurisdição e execução: análise crítica da Lei 9.307, de 23.9.1996. São Paulo: Editora Revista dos Tribunais, 1999. p. 208.

${ }_{13}$ COELHO, João Miguel Galhardo. Arbitragem: legislação nacional, direito internacional, regulamentos, jurisprudência. Coimbra: Livraria Almedina, 2000. p. 119-120.

${ }_{14}$ PITOMBO, Eleonora; STETNER, Renato. A Convenção de Nova lorque: ratificação pelo Brasil. Castro, Barros, Sobral, Gomes Advogados. Disponível em: $<\mathrm{http}: / /$ www.cbsg.com.br/pdf_publicacoes/a_convencao_de_nova_iorque.pdf>. Acesso em [27. out. 2005].
}

Revista Brasileira de Direito Internacional, Curitiba, v.2, n.2, jul./dez.2005 
pars e o "informalismo", o que consubstancia maior satisfação às partes conflitantes.

Salvaguardados todos os planos principiológicos e as circunstâncias acima delineadas, tal como as determinações que a lei específica da arbitragem coloca, respeitando os aspectos de competência e jurisdição e, por fim, haver um julgamento por parte do(s) apreciador(es) de maneira séria e imparcial, o procedimento se dá em conformidade com o explanado em todo o presente estudo, tanto acerca da nomeação dos árbitros (anteriormente avistado) quanto aos pontos a seguir discorridos.

\section{SENTENÇAS PROFERIDAS PELO JUÍZO ARBITRAL}

Havendo sido, portanto, exarado todo o trâmite procedimental, fica a encargo, também pela função que exerce, a decisão do litígio pelo árbitro competente. Essa decisão é justamente o resultado que os litigantes pleiteiam, quando da busca ao órgão de solução de controvérsias.

Assim entende BEZERRA JÚNIOR, trazendo a conceituação do que se tem por uma decisão em âmago arbitral internacional, fundada na competência que os julgadores da lide detêm:

\footnotetext{
“A decisão é sempre obrigatória e sua aceitação prévia encontra-se prevista no próprio compromisso. É sempre escrita, sendo válido o recurso à equiidade, por parte do árbitro. Na realidade, ela tem força obrigatória, mas não força executória, em virtude da inexistência de uma autoridade internacional máxima, competente para exigir seu cumprimento". 15
}

Não obstante, para que a sentença (ou laudo) arbitral conote validade jurídica, afirma LEE que este deve estar investido dos requisitos que the apetecem, como suas condições características. ${ }^{16}$

Mesmo havendo, então, certos atos incidentais ou ordinários no decorrer do procedimento, efetuado pelo(s) árbitro(s), (igualmente existente na jurisdição estatal comum), é a sentença o ato maior que às partes interessa.

\footnotetext{
${ }^{15}$ BEZERRA JÚNIOR, Wilson Fernandes. Arbitragem comercial no direito da integração. São Paulo: Aduaneiras, 2001. p. 121.

${ }^{16}$ LEE, João Bosco. Arbitragem comercial internacional nos países do Mercosul. Curitiba: Juruá, 2002, p. 165.
}

Revista Brasileira de Direito Internacional, Curitiba, v.2, n.2, jul./dez.2005 
Nessa mesma linha é que também se encontra a passagem de FIGUEIRA JÚNIOR, quanto à importância da mesma: "Assim, não podemos definir sentença apenas como sendo o ato que extingue o processo, ou, decisão interlocutória, como aquela que resolve questão não terminativa da demanda. O que substancialmente importa é o conteúdo do pronunciamento do árbitro, ou seja, o seu fundamento intrínseco e ôntico". ${ }^{17}$

Sendo contemplada, na esfera processual civil, a natureza jurídica caracterizadora das sentenças arbitrais, pode-se afirmar que estas se encontram descritas como definitivas e obrigatórias, ou seja: obrigatórias pela necessidade impositiva de julgamento da pendência, por parte do árbitro investido de jurisdição; e definitivas por esgotarem a instância de jurisdição, que é o Tribunal Arbitral.

Nesta órbita, reiterando a compreensão conceitual primordial do instituto da arbitragem e, paulatinamente, com o que dispõe acerca da institucionalização dessa espécie de "jurisdição" no plano prático-efetivo, é admissível explicitar a sua função como elemento de "aceitação de existência" e validade de julgamento. Para isso, transcreve-se o pronunciamento de GLITZ:

\begin{abstract}
"A arbitragem tem como objetivo a solução do conflito através de árbitros escolhidos pelas partes, portanto de sua confiança. As principais vantagens desse sistema são a celeridade, a confidencialidade (o conteúdo da arbitragem fica circunscrito às partes e aos árbitros), a especialização (os árbitros podem ser técnicos) e a possibilidade de decisão por equidade. Para os contratos internacionais justifica-se também pelos custos envolvidos (normalmente mais baixos do que em longas e desgastantes lides judiciais)","
\end{abstract}

É por tal razão que a concepção de um Tribunal Arbitral se faz dificultosa. Imprescindível é o preenchimento dos requisitos legais, objetivos e subjetivos de validade, eficácia e existência para que, assim, seja institucionalizado e digno de julgamentos concisos e imparciais, esperados por seus "jurisdicionados".

17 FIGUEIRA JÚNIOR, Joel Dias. Arbitragem, jurisdição e execução: análise crítica da Lei 9.307, de 23.9.1996. São Paulo: Editora Revista dos Tribunais, 1999. p. 228.

${ }_{18}$ GLITZ, Frederico Eduardo Zenedin. A arbitragem internacional como sistema de solução privada de controvérsias. Jus Navigandi, Teresina: a. 6, n. 59, out. 2002. Disponível em: $<$ http://jus2.uol.com.br/doutrina/texto.asp?id=3260 >. Acesso em [05. out. 2005].

Revista Brasileira de Direito Internacional, Curitiba, v.2, n.2, jul./dez.2005 
A despeito da sentença arbitral propriamente dita, esta será devidamente fundamentada (segundo entendimento jurídico do árbitro ao caso in concretu) e constituída de forma solene, conforme disposição do art. 24, caput da Lei de Arbitragem e assinado pelo árbitro (ou pelo colégio), dando validade jurídica ao ato. Para tanto, há o resguardo legal, ainda, (art. 26, § único), de emissão de um certificado caso o(s) julgador(es) não firmarem a sentença ou não puderem fazê-lo em momento oportuno.

Com a convalidação da sentença, motivado pelo árbitro competente da solução do litígio, a mesma transforma-se em título executivo judicial (art. 584, VI, CPC). No entanto, os desdobramentos de reconhecimento desse título e posterior execução serão analisados subsequentemente.

Destarte, a Lei nº 9.307/96, no art. $24, \S 1^{\circ}$, confere como voto válido e passível de resultado apreciativo do deslinde o entendimento majoritário e acordado, quando a sentença for proferida pelo colégio arbitral. Assim, estando votada a solução de controvérsia, extingue o poder jurisdicional conferido ao árbitro, exceto em casos de embargos de declaração ou erro material (art. 30) que, por vez, logicamente deverá resolver.

Acerca do prazo, a regra geral, caso não tenha sido predeterminado convenção das partes em contrário, é de seis meses, (segundo art. 23, caput), da instituição do litígio ou substituição de julgador, se assim entender ser necessário. Não obstante, havendo acordo por parte dos litigantes sobre o prazo de julgamento, este poderá ser protelado até quanto for preciso, (autonomia da vontade das partes, crivada no art. 23, § único).

Caso a disposição acima não seja configurada e/ou obedecida, tornase possível a sua nulidade, prevista no art. 32. Dessa maneira, para que a validade jurídica de uma sentença de natureza arbitral encontre-se efetiva, os requisitos, anteriormente discorridos e ora mencionados, segundo entendimento de ARAUJO, caracterizam todo o aparato do procedimento que a ela se faz concernente, na órbita de seu pronunciamento nacional:

\footnotetext{
"A sentença ou laudo arbitral proferida no Brasil precisa conter, obrigatoriamente, os seguintes requisitos: (a) relatório com nome das partes e resumo do litígio; (b) fundamentos da decisão; (c) dispositivo no qual consta a decisão dos árbitros e prazo para cumprimento; (d) data e local onde foi
} 
proferida. A ausência de motivação da sentença, bem como de quaisquer dos requisitos acima mencionados, acarretará a sua nulidade". ${ }^{19}$

In fine, fica assinalado que a sentença (ou laudo) arbitral pressupõe o preenchimento básico de vários requisitos e pressupostos para demonstrar como sendo um documento passível de execução, tanto no país em que foi proferida quanto em país adverso. Neste último, portanto, é preciso sua homologação, como será adiante analisado.

Assim sendo, a importância conferida às sentenças arbitrais, por haverem força decisiva definitiva, deve ser cautelosamente esmiuçada, visto que a interpretação do caso pelos julgadores ensejou assim sua decisão e esta, por sua vez, compreende o valor buscado pelos litigantes, quando da apreciação da lide, por via arbitral.

\section{FASES RECURSAIS ADMISSÍVEIS}

Conforme exposto até o presente momento, ao Tribunal Arbitral compete, pela sua função constitutiva, processar e sentenciar acercados desentendimentos, decorrentes de inadimplemento, por uma ou ambas as partes de certa obrigação por elas estipulada, visando a prolação do laudo arbitral, de árbitro conveniente, que venha a solucionar tal pendência.

Aos tribunais dessa natureza, tal como ocorre na jurisdição interna de determinado país, não se podem suprir os níveis ou graus jurisdicionais, ou seja, ao instituto arbitral também se aplica o fundamento do duplo grau de jurisdição, (princípio norteador, positivado de forma implícita no art. 5ำ da Carta Magna brasileira). Nesse sentido, havendo possibilidade disso, afirma-se que em relação às sentenças (ou laudo) arbitrais proferidas, é entendível sua instância recursiva. Por isso, os tipos recursais cabíveis contra sentença arbitral proferida são válidos e integram o trâmite jurisdicional completo que a ela se assevera. Para tal, limitamo-nos a análise dos seguintes recursos, para relevância que expressam: a) ação anulatória; b) erro material ou formal e

\footnotetext{
${ }^{19}$ ARAUJO, Nadia de. Direito internacional privado: teoria e prática brasileira. 2.ed. Rio de Janeiro: Renovar, 2004. p. 431.
}

Revista Brasileira de Direito Internacional, Curitiba, v.2, n.2, jul./dez.2005 
embargos de declaração; c) embargos à execução. Ainda será mencionado a respeito da apelação em órbita arbitral, sem que, portanto, sejam conferidos maiores detalhes.

Em referência a ação conhecida por "anulatória" tem-se, como escopo, a possibilidade de decretação de nulidade do teor do laudo arbitral, quando os pressupostos deste não forem obedecidos integralmente, em consonância aos arts. 10, 21, § 2o, 26 e 32, todos da Lei de Arbitragem. Havendo interesse em que a disposição arbitral seja anulada, cabe à parte a instauração do processo, em congruência ao art. 282 da lei processual civil, ao órgão provido de legitimidade, para que assim se possa consolidar o pleito anulatório. ${ }^{20}$

No plano do Mercosul, então, esta ação apresenta tamanha importância como forma de recurso possível, em via arbitral, que LEE afirma como sendo a única delas reconhecida por todos os países do bloco:

\footnotetext{
"Ao contrário da apelação, o tribunal estatal competente para julgar o recurso de anulação não revisa o mérito da sentença arbitral. Trata-se de um controle de regularidade da sentença. No quadro do Mercosul, a anulação de sentença arbitral é o único meio reconhecido por todas as legislações. Esses países adotam, entretanto, procedimentos diferentes para a demanda de nulidade da sentença (A); os motivos sobre os quais se funda são igualmente diversos (B)" $21^{\prime}$
}

Dessa forma, de grande valia se faz o instituto da ação anulatória, dando respaldo à concretude e convalidação do ato sentencial de Tribunal Arbitral, conforme os ditames de requisitos necessários, sob pena de nulidade.

Quando a sentença arbitral for tomada e nela haver erro material ou mesmo formal, em seu corpo, dar-se-á ensejo ao chamado "embargos de declaração", com o intuito de a parte pedir esclarecimentos ou correções necessárias em certo(s) ponto(s) do laudo. O prazo para intentar o tipo recursal é de cinco dias, contados do recebimento da notificação do laudo ou então da intimação efetuada, pessoalmente.

Efetuado o pedido de esclarecimento da "obscuridade" do teor do laudo arbitral, seja qual for o motivo (erro material ou formal) fica(m) o(s) árbitro(s)

${ }^{20}$ FIGUEIRA JÚNIOR, Joel Dias. Arbitragem, jurisdição e execução: análise crítica da Lei 9.307, de 23.9.1996. São Paulo: Editora Revista dos Tribunais, 1999. p. 269-270.

${ }^{21}$ LEE, João Bosco. Arbitragem comercial internacional nos países do Mercosul. Curitiba: Juruá, 2002. p. 201.

Revista Brasileira de Direito Internacional, Curitiba, v.2, n.2, jul./dez.2005 
adstrito(s) ao prazo de dez dias para corrigi-lo. Esse recurso é interessante para que não se tenha entendimento errôneo após a convalidação da sentença e posterior obediência àquilo que não necessariamente era a vontade do apreciador em julgar.

Caso o laudo arbitral se mostre de maneira condenatória a um dos litigantes, será, via de regra, efetuada a fase executória do título concedido. Desse modo, se dará a execução de tal título judicial (oriundo do tribunal arbitral), o que caracteriza de interesse do executado, os embargos do processo executório, conforme previsão do CPC (a partir do art. 741).

Confrontando os embargos à execução com o que se encontra positivado na Lei no 9.307/96, FIGUEIRA JUNIOR tece comentários ponderantes: "Os embargos à execução fundados em qualquer dos incisos do art. 32 da Lei da Arbitragem obstam o ajuizamento posterior de ação anulatória baseada nos mesmos fatos e fundamentos jurídicos, cabendo à parte interessada argüir exceção de litispendência ou coisa julgada". ${ }^{22}$

Por tal fato, às lides constituidoras de título executivo, é presumível a fase concernente à sua execução, (nos ditames da Lei de Arbitragem), seus embargos, conforme observado, também se fazem presentes. A apelação, in summa, é o tipo recursal ordinário de qualquer sentença, porém, na via arbitral, ela será aceita tão-somente em alguns juízos, ou naqueles em que sua utilização seja prevista como viável e válida.

Assim sendo, fica demonstrada, em linhas gerais, a necessidade de existir o duplo grau jurisdicional, também em âmago arbitral internacional, bem como acerca das formas recursais e suas finalidades, para cada caso e em conformidade com a necessidade dela usufruir. Fica consolidada a caracterização, assim, de um tipo jurisdicional que se encontra concernente aos tribunais arbitrais.

\footnotetext{
${ }^{22}$ FIGUEIRA JÚNIOR, Joel Dias. Arbitragem, jurisdição e execução: análise crítica da Lei 9.307, de 23.9.1996. São Paulo: Editora Revista dos Tribunais, 1999. p. 269-271.
}

Revista Brasileira de Direito Internacional, Curitiba, v.2, n.2, jul./dez.2005 


\section{RECONHECIMENTO DOS LAUDOS ARBITRAIS E SUA EXECUÇÃO EM TERRITÓRIO ESTRANGEIRO}

Após todo o processamento da lide pela via arbitral, sua declaração de julgamento por meio de sentença, ou laudo arbitral e posterior consideração de que tal decisão, pelas partes litigantes, é válida, sua homologação deve ser efetuada, por intermédio do reconhecimento de seu teor para, em momento certo, tornar-se exeqüível.

O processamento da contenda, pelo juízo arbitral, tem por escopo a busca plena dos direitos, fundado na segurança jurídica, e proteção (de adimplemento) de certa obrigação que foi firmada e não cumprida por uma das partes. Portanto, havendo essa discrepância e após a utilização dos meios suasórios de resolução conflitante, tem-se a sentença, consoante visto anteriormente.

No entanto, já havendo sido julgado, pelo árbitro competente ou colégio arbitral o deslinde, sua efetividade, como título executivo judicial, se tem resguardada. Dessa forma, existe a necessidade de o laudo ser reconhecido como válido, acarretando as conseqüências jurídicas cogentes, em território diverso àquele que julgou.

Acerca do procedimento a ser adotado para que as sentenças arbitrais estrangeiras, bem como sua execução, sejam realizadas, em território nacional, encontram-se descritos na Lei de Arbitragem (Lei o 9.307/96), compreendidos entre os arts. 34 e 40. Sua regulação traz, em seu bojo, a conceituação do que se entende por "sentença arbitral estrangeira" e as formas possíveis de as mesmas poderem ser fielmente executadas no Brasil.

Necessário, de plano, assinalar que no ano de 2004, por força da Emenda Constitucional no 45, a chamada "Reforma do Judiciário"23, revogou-se a competência do Superior Tribunal Federal para a homologação de laudos arbitrais, exaurindo a alínea "h" do inciso I do art. 102 da Constituição Federal,

\footnotetext{
${ }^{23}$ A EC no 0 45/04 trouxe alterações significativas ao plano processual, dentre outros, no que diz respeito aos dispositivos constitucionais. Por tal motivo, convencionou-se chamá-la de "Reforma do Judiciário".
}

Revista Brasileira de Direito Internacional, Curitiba, v.2, n.2, jul./dez.2005 
outorgando-a, para tal, ao Superior Tribunal de Justiça, consoante a alínea "i", do inciso I do art. 105, do mesmo diploma constitucional.

Dessa maneira, ficou ao encargo do STJ processar e julgar, originariamente, a homologação de sentenças advindas do estrangeiro, bem como a concessão de exequatur, relativas às cartas rogatórias.

Não obstante, então, para que as sentenças arbitrais estrangeiras (já esmiuçadas anteriormente) sejam passíveis de execução, ARAUJO entende a obrigação de se sujeitarem à homologação, pelo Supremo Tribunal Federal (hoje alterado para a alçada do Superior Tribunal de Justiça, conforme acima delineado, pela EC 45/04), para que, desse modo, se possa dar continuidade ao processo. Assim ocorre pelo poder constitucional conferido ao STJ, para tal momento apreciativo (atualizado). ${ }^{24}$

Com entendimento equivalente, ROQUE explicita, cautelosamente, como é feita a requisição de homologação de sentença dessa natureza, pela parte, ao órgão anteriormente competente, doravante alterado para o STJ:

\begin{abstract}
“A homologação de sentença arbitral estrangeira será requerida pela parte interessada, ao Supremo Tribunal Federal, em petição inicial, tal como é regulamentada pelo art. 297 do CPC. Obrigatoriamente, será a petição inicial instruída com o original da convenção de arbitragem ou cópia devidamente certificada, acompanhada da tradução oficial. O processo de homologação seguirá o rito previsto nos arts. 110 a 224 do Regimento Interno do Supremo Tribunal Federal. Essas decisões da Excelsa Corte são normalmente publicadas nas revistas especializadas". 25
\end{abstract}

A homologação por tal Corte brasileira, portanto, é pré-requisito para que a sentença arbitral, proferida em país diverso, seja reconhecida no território nacional.

Por conta, os requisitos genéricos a serem preenchidos para que tal reconhecimento se tenha por certo são os: a) positivos (aqueles que devem, necessariamente, estar presentes para que o pleito seja acolhido) e b) negativos (elementos impeditivos para que o mesmo seja admissível ao

\footnotetext{
${ }^{24}$ ARAUJO, Nadia de. Direito internacional privado: teoria e prática brasileira. 2.ed. Rio de Janeiro: Renovar, 2004. p. 434.

${ }^{25}$ ROQUE, Sebastião José. Arbitragem: a solução viável. São Paulo: Ícone, 1997. p. 98.
}

Revista Brasileira de Direito Internacional, Curitiba, v.2, n.2, jul./dez.2005 
território em questão). Em havendo atendimento a estes, o STJ não terá como recusar o pedido de homologação da sentença (atualizado). ${ }^{26}$

A jurisprudência, anteriormente à "Reforma do Judiciário" assim entende acerca da homologação demonstrado em casos já julgados conforme este abaixo trasladado, conforme comenta LENZA:

"O STF teve também a oportunidade de conceder exequatur no caso La Pastina S.A. vs. Centro Fins S.A. Foi homologado laudo arbitral proferido pelo Tribunal Arbitral Amigável de Hamburgo, contrário à empresa brasileira, em matéria de compra e venda mercantil. O laudo foi ratificado pela Justiça da Alemanha, transmitindo-lhe a qualidade de sentença jurisdicional e permitindo sua homologação, a fim de produzir efeitos no Brasil. (Publicado no Diário da Justiça da União, de 14 de dezembro de 1979, p. 9.443)", 27

Portanto, é aceitável dizer que o procedimento homologatório de sentença de natureza estrangeira é simples, bastando, apenas, que os pressupostos concernentes sejam prontamente acolhidos. Neste caso, ao Superior Tribunal de Justiça compete o reconhecimento, somente podendo ser denegada, sob a forma da lei, nas hipóteses que abaixo se seguem.

Para que o reconhecimento da homologação não se faça válido, a Lei de Arbitragem (de no 9.307/96) enumera as suposições em seu art. 38 que, por sua vez, fundam-se nas Convenções de Nova lorque (1958) e do Panamá (1975):

\begin{abstract}
“Art. 38. Somente poderá ser denegada a homologação para o reconhecimento ou execução de sentença arbitral estrangeira, quando o réu demonstrar que: I) as partes na convenção de arbitragem eram incapazes; II) a convenção de arbitragem não era válida segundo a lei à qual as partes a submeteram, ou, na falta de indicação, em virtude da lei do país onde a sentença arbitral foi proferida; III) não foi notificado da designação do árbitro ou do procedimento de arbitragem, ou tenha sido violado o princípio do contraditório, impossibilitando a ampla defesa; IV) a sentença arbitral foi proferida fora dos limites da convenção de arbitragem e não foi possível separar a parte excedente daquela submetida à arbitragem; V) a instituição da arbitragem não está de acordo com o compromisso arbitral ou cláusula compromissória; VI) a sentença arbitral não tenha, ainda, tornado obrigatória para as partes, tenha sido anulada, ou, ainda, tenha sido suspensa por órgão judicial do país onde a sentença arbitral for prolatada".
\end{abstract}

${ }^{26}$ FIGUEIRA JÚNIOR, Joel Dias. Arbitragem, jurisdição e execução: análise crítica da Lei 9.307, de 23.9.1996. São Paulo: Editora Revista dos Tribunais, 1999. p. 282-283.

${ }^{27}$ LENZA, Vítor Barboza. Cortes arbitrais (CA). 2.ed. Goiânia: AB, 1999. p. 185. 
Assim, por fim, o procedimento de homologação é efetuado, na esfera brasileira, quando de um pedido pela parte, de reconhecimento de sentença arbitral proferida no estrangeiro ao órgão competente para tal, qual seja: 0 tribunal de jurisdição nacional (STJ).

Acerca da execução da sentença arbitral estrangeira, que, por vez, já deve se encontrar homologada pelo STJ, necessita se dar em congruência aos tratados (de âmbito internacional) que estejam inseridos no ordenamento jurídico interno do país. No que dispõe sobre o Brasil, caso tais tratados sejam omissos ou não existam, dar-se-á pela própria Lei de Arbitragem, legislação processual civil vigente e pelo Regimento Interno da Corte em questão.

Existindo o julgamento, pela via arbitral, da lide entre as partes, tem-se a sentença, (proferida pelos apreciadores investidos de aptidão para tal). Esta sentença, para que detenha validade jurídica noutro território, ao qual se pretende executar, prescinde de homologação pelo órgão judiciário competente. Após este reconhecimento se tem por apropriada a possibilidade de execução, ressaltando que o mesmo caracteriza-se por procedimento exclusivo.

O processo executório inicia, em posterior momento da homologação da sentença, pela retirada da carta de sentença do processo homologatório, constituindo o modus probandi necessário. A execução, a partir da extração desta carta, será de maneira ordinária àquela disposta no $\mathrm{CPC}$, (consoante 0 art. 484), remetendo ao procedimento do art. 224 do mesmo Códex.

É preciso deixar claro que a fase executória da sentença arbitral homologada é indispensável, ou seja, não se tem por aceitável que a mesma, já reconhecida em território diverso daquele que julgou, não se faça eficaz, em seu plano jurídico. Nestes termos, LOBO assim entende:

\footnotetext{
"No que tange à arbitragem, cabe ao Tribunal nomear ou confirmar os árbitros, ser informado dos trâmites do processo, examinar os projetos das sentenças arbitrais, às quais pode recusar reconhecimento nos casos taxativamente previstos no Tratado. As sentenças arbitrais têm força de coisa julgada e são objeto de execução obrigatória" ${ }^{28}$
}

\footnotetext{
${ }^{28}$ LOBO, Maria Teresa de Carcomo. Integração regional africana. IAB Nacional. Disponível em: $<\mathrm{http}: / / \mathrm{www}$.iabnacional.org.br/comm/comissaopermanentededireitocomunitario.html>. Acesso em [12. out. 2005].
}

Revista Brasileira de Direito Internacional, Curitiba, v.2, n.2, jul./dez.2005 
Enfim, a competência para o processamento e julgamento da execução de sentença estrangeira, depois de sua homologação é, segundo preceito constitucional (art. 109, X), dos juízes federais, combinado com a disposição do art. 88 do CPC, referente à competência internacional (como regra geral) ou então pelo acordo precedente das partes, na convenção arbitral.

Todo o momento proveniente da busca de julgamento de certo litígio por meio de tribunal arbitral se tem por complexo e não sendo menos árduo do que se ocorresse em juízo interno comum. Para tanto, mesmo havendo tal "morosidade", a via arbitral é interessante às partes que dela utilizam-se por estarem intrínsecos o "princípio da vontade das partes" e a maneira única de poder trazê-lo ao plano interno do país, para a execução da sua sentença.

\section{CONSIDERAÇÕES FINAIS}

A inserção do juízo arbitral como forma operante de solução litigiosa, no momento da formação do Tribunal Arbitral de espécie internacional, como objetivo de se chegar à pacificação da lide de sujeitos de direito de diferentes nações, traz consigo certo recondicionamento e uma visão progressista de que a jurisdição não se limita tão-somente para processar e julgar as pendências de modo "coercitivo", mas sim pela vontade que as partes expõem, facilitando a harmonia e a satisfação "pós-litígio". Tal vantagem se faz característica por meio da arbitragem.

Mesmo sendo ainda um tanto utópico o fato de a arbitragem internacional vir a se consolidar, com a segurança jurídica que the é devida, nos próximos anos, fica a reflexão de que sua atuação junto às partes que dela recorrem é interessante, em especial pela satisfação que as mesmas expressam acerca do pronunciamento do laudo arbitral, visto que a vontade dos litigantes é pressuposto, assim como é levado em consideração, no procedimento arbitral.

Assim compreende FIGUEIRA JÚNIOR quando explana sua reflexão conclusiva sobre a utilização do instituto da arbitragem no Brasil e no mundo: 


\begin{abstract}
"Enquanto o Brasil ainda não adquiriu o hábito, e, por conseguinte, a tradição de utilizar-se da arbitragem para solução de inúmeros conflitos, nada obstante o instituto sempre ter estado presente em nossos sistemas normativos - e diga-se de passagem, com a legislação que possuíamos até então o resultado não poderia ser mais alentador - outros países têm feito uso freqüente desse instituto, cujos efeitos são altamente vantajosos para todos, sobretudo nas questões de natureza mercantil, diante da rapidez e economia com que as demandas são solucionadas, seja em nível nacional ou internacional". ${ }^{29}$
\end{abstract}

Não se pode deixar banalizar um instituto como o da arbitragem internacional (ou mesmo interna) pela escassez de recursos e viabilidade dos litigantes a ela se chegar. A arbitragem que foi imaginada e posteriormente legalizada (pela Lei no 9.307/96, embasada na Lei Modelo da UNCITRAL ${ }^{30}$ ) em nosso ordenamento deve estar em atividade a todo tempo, auxiliando a justiça comum a aliviar suas exorbitantes montas de processos a serem julgados.

Todavia, a jurisdição de plano arbitral, mesmo ainda andando a passos lentos, já apresenta, internacionalmente pensando, resultados de cunho satisfatório, trazidos pela eficiência que os componentes desses juízos (árbitros, servidores e até mesmo as partes) demonstram. A competência dos tribunais arbitrais ainda é limitada, porém isso não descaracteriza a necessidade de expansão dessa competência, tal como da quantidade de juízos, o que atualmente se manifesta carente, pelo Direito Internacional Privado.

A formação, então, do Tribunal Arbitral é requisito primordial para que se faça evidente uma "jurisdição alternativa", investida de competência para tanto, mas que venha a externar verdadeira vontade de consolidar-se como órgão sério (no que se refere à atividade que executa) e formador de jurisprudência internacional.

Estando compreendido o momento arbitral em estudo, deve-se destacar que aos entendimentos doutrinários se faz contundente denotar importância para que o instituto da arbitragem, sob as diversas maneiras expostas pelos estudiosos da área, traga justamente o fim a que se espera de

\footnotetext{
${ }^{29}$ FIGUEIRA JÚNIOR, Joel Dias. Arbitragem (legislação nacional e estrangeira) e o monopólio jurisdicional. São Paulo: LTr, 1999. p. 39.

${ }^{30}$ UNCITRAL - United Nations Commission on International Trade Law (Comissão das Nações Unidas para o Direito Comercial Internacional).
}

Revista Brasileira de Direito Internacional, Curitiba, v.2, n.2, jul./dez.2005 
um processamento válido de litígios fora da alçada jurisdicional ordinária, qual seja: a eficiência, a celeridade, a imparcialidade e a justiça a qualquer custo.

Por derradeiro, ao Direito Internacional Privado cabe a fiscalização dos tribunais arbitrais de cunho supranacional, fundada nos princípios norteadores que preconizam sua existência. Havendo um trabalho veemente em prol da arbitragem internacional, não se encontra qualquer entrave (legal ou de aspecto diverso) para que seu sucesso absoluto se materialize, de maneira duradoura.

\section{REFERÊNCIAS}

ARAUJO, Nadia de. Direito internacional privado: teoria e prática brasileira. 2.ed. Rio de Janeiro: Renovar, 2004.

BEZERRA JÚNIOR, Wilson Fernandes. Arbitragem comercial no direito da integração. São Paulo: Aduaneiras, 2001.

COELHO, João Miguel Galhardo. Arbitragem: legislação nacional, direito internacional, regulamentos, jurisprudência. Coimbra: Livraria Almedina, 2000.

FIGUEIRA JÚNIOR, Joel Dias. Arbitragem (legislação nacional e estrangeira) e o monopólio jurisdicional. São Paulo: LTr, 1999.

. Arbitragem, jurisdição e execução: análise crítica da Lei 9.307, de 23.9.1996. São Paulo: Editora Revista dos Tribunais, 1999.

GLITZ, Frederico Eduardo Zenedin. A arbitragem internacional como sistema de solução privada de controvérsias. Jus Navigandi, Teresina: a. 6, n. 59, out. 2002. Disponível em: <http://jus2.uol.com.br/doutrina/texto.asp?id=3260>. Acesso em [05. out. 2005].

LEE, João Bosco. Arbitragem comercial internacional nos países do Mercosul. Curitiba: Juruá, 2002.

LENZA, Vítor Barboza. Cortes arbitrais (CA). 2.ed. Goiânia: AB, 1999. p. 185.

LOBO, Maria Teresa de Carcomo. Integração regional africana. IAB Nacional. Disponível em:

$<$ http://www.iabnacional.org.br/comm/comissaopermanentededireitocomunitario .html>. Acesso em [12. out. 2005]. 
MAGALHÃES, José Carlos de. Do procedimento arbitral, p. 155-169. In: PUCCI, Adriana Noemi (coord.). Aspectos atuais da arbitragem: coletânea de artigos sobre arbitragem. Rio de Janeiro: Forense, 2001.

MARQUES, José Frederico. Manual de direito processual civil. v. 1. São Paulo: Saraiva, 1978.

MELLO, Celso D. de Albuquerque. Curso de direito internacional público, v.2. 13.ed. Rio de Janeiro: Renovar, 2001.

PITOMBO, Eleonora; STETNER, Renato. A Convenção de Nova lorque: ratificação pelo Brasil. Castro, Barros, Sobral, Gomes Advogados. Disponível em:

$<h t t p: / / w w w . c b s g . c o m . b r / p d f \_p u b l i c a c o e s / a \_c o n v e n c a o \_d e \_n o v a \_i o r q u e . p d f>$. Acesso em [27. out. 2005].

ROQUE, Sebastião José. Arbitragem: a solução viável. São Paulo: Ícone, 1997. 